\title{
SULFOTRANSFERASE ACTIVITY IN PLUCKED HAIR FOLLICLES PREDICTS RESPONSE TO TOPICAL MINOXIDIL TREATMENT IN BRAZILIAN FEMALE PATTERN HAIR LOSS PATIENTS
}

\author{
Authors: \\ Paulo Müller Ramos, MD, MScㄹ; Rodney Sinclair, MD, PhD²; Hélio Amante \\ Miot, $\mathrm{MD}, \mathrm{PhD}^{1}$; Andy Goren, $\mathrm{MD}^{3}$ \\ ${ }^{1}$ Department of Dermatology and Radiotherapy, São Paulo State University - \\ UNESP, Botucatu, SP, Brazil. \\ 2 Sinclair Dermatology, Melbourne, VIC, Australia \\ ${ }^{3}$ Applied Biology, Inc.Irvine, California, USA
}

\section{Correspondence:}

Paulo Müller Ramos

Av; Prof. Mário Rubens Guimarães Montenegro, sn

UNESP - Campus Botucatu

18618687 - Botucatu - SP

Email: dermato.paulo@gmail.com

Phone/FAX: +55 43999125333

\section{Word count: 497}

This is the author manuscript accepted for publication and has undergone full peer review but has not been through the copyediting, typesetting, pagination and proofreading process, which may lead to differences between this version and the Version of Record. Please cite this article as doi: $10.1111 /$ dth.13195

This article is protected by copyright. All rights reserved. 
Figures/Tabels: 1

Short title: Sulfotransferase Activity in Brazilian Female Pattern Hair Loss Patients

Conflict of interest: no conflict of interest

KEYWORDS: sulfotransferase, female pattern hair loss, minoxidil, brazilian 
Topical minoxidil is the only medication approved by US Food and Drug Administration for the treatment of female pattern hair loss (FPHL). Less than $40 \%$ of patients achieve clinical improvement with the treatment.

Minoxidil is a prodrug converted to minoxidil sulfate by the sulfotransferase enzyme in the hair follicle outer root sheet (ORS) (Buhl, Waldon, Baker, \& Johnson, 1990) There is a correlation between sulfotransferase enzyme activity in plucked hair samples and response to minoxidil therapy in androgenetic alopecia patients (Roberts, Desai, McCoy, \& Goren, 2014).

Considerable inter-individual variation in sulfotransferase activity is observed in human due to polymorphisms in the coding regions of sulfotransferase genes (Gamage et al., 2006). The percentage of subjects with low levels of sulfotransferase enzyme activity varies in different populations (Chitalia et al., 2018).

In this communication, we aim to evaluate ORS minoxidil sulfotransferase activity in relation to change in hair density in Brazilian patients with FPHL using 5\% minoxidil for 24 weeks.

Eight female subjects with Sinclair Stage II-IV FPHL were recruited from a hospital dermatology department to participate in an open label study applying $5 \%$ topical minoxidil once a day for a period of 24 weeks. Hair density was assessed by phototrichogram. Participants received a mini tattoo in the 
parietal region that was representative of the area of patient hair loss prior to treatment (week 0). A circular template of $2.2 \mathrm{~cm}^{2}$ was centered over the mini tattoo. Hairs inside the template were clipped to approximately $0.5 \mathrm{~mm}$ in length. A 10-fold enlargement dermatoscopic digital image was performed. The tattoo was used to ensure that the phototrichogram repeated after 24 weeks of treatment was taken from the same area of the scalp.

At the end of the study, 10 anagen hairs were plucked from the border between the most prominent area of thinning and non-thinning at the vertex scalp from each subject for assessment of sulfotransferase enzymatic activity. The sulfotransferase assay was performed according to prior description (Roberts et al., 2014). We used the previous validated value of less than 0.4 absorbance unites (AU) as a marker for low follicular sulfotransferase activity (Roberts et al., 2014).

The descriptive data of the sample is summarized in Table 1. Participants with increased hair counts were classified as responders and participants with decreased hair counts were classified as non-responders. The prevalence adjusted negative predictive value (NPV) and positive predictive value (PPP) were calculated using Bayes Theorem with a responder prevalence of $39 \%$ to topical minoxidil. The NPV was $82.43 \%(95 \% \mathrm{Cl}: 43.95 \%, 96.56 \%)$ and the PPV was $65.73 \%$ (95\% Cl: 24.27\%, 91.99\%).

The sulfotransferase enzyme activity in plucked hair follicles is a predictive marker for minoxidil response in Caucasian, Asian, and Indian 
populations. While our study size was small, the large NPV observed in our Brazilian population is consistent with a previous study that presented NPV of 95.94\% (Goren et al., 2015); therefore, among Brazilian women with FPHL, determining the sulfotransferase activity in plucked hair follicles provides clinical utility in guiding treatment regimen.

\section{REFERENCES}

Buhl, A. E., Waldon, D. J., Baker, C. A., \& Johnson, G. A. (1990). Minoxidil sulfate is the active metabolite that stimulates hair follicles. J Invest Dermatol, 95(5), 553-557.

Chitalia, J., Dhurat, R., Goren, A., McCoy, J., Kovacevic, M., Situm, M., . . Lotti, T. (2018). Characterization of follicular minoxidil sulfotransferase activity in a cohort of pattern hair loss patients from the Indian Subcontinent. Dermatol Ther, 31(6), e12688. doi:10.1111/dth.12688

Gamage, N., Barnett, A., Hempel, N., Duggleby, R. G., Windmill, K. F., Martin, J. L., \& McManus, M. E. (2006). Human sulfotransferases and their role in chemical metabolism. Toxicol Sci, 90(1), 5-22. doi:10.1093/toxsci/kfj061

Goren, A., Shapiro, J., Roberts, J., McCoy, J., Desai, N., Zarrab, Z., . . Lotti, T. (2015). Clinical utility and validity of minoxidil response testing in androgenetic alopecia. Dermatol Ther, 28(1), 13-16. doi:10.1111/dth.12164

Roberts, J., Desai, N., McCoy, J., \& Goren, A. (2014). Sulfotransferase activity in plucked hair follicles predicts response to topical minoxidil in the treatment of female androgenetic alopecia. Dermatol Ther, 27(4), 252-254. doi:10.1111/dth.12130

This article is protected by copyright. All rights reserved. 
Table 1. Descriptive data of the sample.

\begin{tabular}{lcccc}
\hline Pt. No & Age (years) & AU & Hair Count Before & Hair Count After \\
\hline $\mathbf{1}$ & 41 & 0.158 & 200 & 190 \\
$\mathbf{2}$ & 49 & 0.180 & 180 & 192 \\
$\mathbf{3}$ & 57 & 0.404 & 82 & 97 \\
$\mathbf{4}$ & 54 & 0.410 & 95 & 105 \\
$\mathbf{5}$ & 65 & 0.419 & 127 & 125 \\
$\mathbf{6}$ & 59 & 0.285 & 113 & 110 \\
$\mathbf{7}$ & 32 & 0.466 & 120 & 130 \\
$\mathbf{8}$ & 48 & 0.168 & 122 & 118 \\
\hline
\end{tabular}

This article is protected by copyright. All rights reserved. 
Table 1. Descriptive data of the sample.

\begin{tabular}{lcccc}
\hline Pt. No & Age (years) & AU & Hair Count Before & Hair Count After \\
\hline $\mathbf{1}$ & 41 & 0.158 & 200 & 190 \\
$\mathbf{2}$ & 49 & 0.180 & 180 & 192 \\
$\mathbf{3}$ & 57 & 0.404 & 82 & 97 \\
$\mathbf{4}$ & 54 & 0.410 & 95 & 105 \\
$\mathbf{5}$ & 65 & 0.419 & 127 & 125 \\
$\mathbf{6}$ & 59 & 0.285 & 113 & 110 \\
$\mathbf{7}$ & 32 & 0.466 & 120 & 130 \\
$\mathbf{8}$ & 48 & 0.168 & 122 & 118 \\
\hline
\end{tabular}

This article is protected by copyright. All rights reserved. 


\section{University Library}

\section{- M M N E R VA A gateway to Melbourne's research publications}

Minerva Access is the Institutional Repository of The University of Melbourne

Author/s:

Ramos, PM;Sinclair, R;Miot, HA;Goren, A

Title:

Sulfotransferase activity in plucked hair follicles predicts response to topical minoxidil treatment in Brazilian female pattern hair loss patients

Date:

2020-01-01

Citation:

Ramos, P. M., Sinclair, R., Miot, H. A. \& Goren, A. (2020). Sulfotransferase activity in plucked hair follicles predicts response to topical minoxidil treatment in Brazilian female pattern hair loss patients. DERMATOLOGIC THERAPY, 33 (1), https://doi.org/10.1111/dth.13195.

Persistent Link:

http://hdl.handle.net/11343/286790 